\title{
ARTYKUŁY
}

Joanna Lubierska

(Wielkopolskie Towarzystwo Genealogiczne „Gniazdo")

joanna.lubierska@gmail.com

Dobrosława Gu cia

(Wielkopolskie Towarzystwo Genealogiczne "Gniazdo")

gucia11@gmail.com

\section{Skonfliktowany z prawem przodek. Listy gończe końca XVIII i pierwszej połowy XIX w. jako źródło w badaniach genealogicznych}

Od ponad dziesięciu lat obserwujemy wzrastające zainteresowanie historią własnej rodziny i związane z tym powstawanie towarzystw genealogicznych skupiających liczne rzesze genealogów-amatorów. W ramach tych towarzystw realizowane są m.in. projekty genealogiczne dostępne on-line ${ }^{1}, \mathrm{z}$ wyników których korzystają także naukowcy, regionaliści, studenci czy inne osoby zainteresowane tematyką popularnogenealogiczną.

Prowadzenie badań nad przeszłością własnej rodziny nie jest przedsięwzięciem łatwym. O ile stosunkowo prosto jest zgromadzić podstawowe dane o członkach najbliższej rodziny, o tyle zdobycie choć drobnej informacji poszerzającej stan naszej wiedzy o nich wiąże się często z wieloetapowymi poszukiwaniami i wyczerpującą kwerendą, szczególnie jeśli pochodzimy $z$ rodzin chłopskich, $z$ małych osad i wsi. Mimo że mamy do dyspozycji opracowania historyków i materiały źródłowe, jednakże najczęściej dotyczą one wieków wcześniejszych, tych, w których genealog-potomek włościanina żadnych, lub prawie żadnych, informacji dla siebie nie znajdzie. Mało jest opracowań i źródeł z XVIII i XIX w. ukazują rozwój tej warstwy społecznej lub

\footnotetext{
${ }^{1}$ Przykładowo projekty dotyczące Wielkopolski: Poznan Project - ma na celu zindeksowanie akt małżeństw z terenu Wielkopolski i Kujaw z lat 1800-1899. Obecnie w bazie jest 1341783 rekordów (stan na 29 lutego 2016 r.), projekt dostępny na pod adresem http:/ / poznan-project.psnc.pl/search. php (dostęp 15 czerwca 2016); BaSIA, czyli Baza Systemu Indeksacji Archiwalnej - ma na celu udostępnianie wyszukiwarki dla indeksów ksiąg metrykalnych (urodzenia, zgony, śluby), obejmujących szeroko pojętą Wielkopolskę, baza zawiera 2905514 wpisów (stan na 2 kwietnia 2016), projekt dostępny na pod adresem http:/ / www.basia.famula.pl/ (dostęp 15 czerwca 2016).
} 
poszczególnych miasteczek i wsi. Historycy opracowują źródła zazwyczaj z XIV-XVI w., a niekiedy siedemnastowieczne, niestety, tam naszych przodków pochodzących ze wsi nie ma, jest natomiast szlachta i możnowładztwo oraz duchowieństwo.

$\mathrm{Z}$ inicjatywy towarzystw genealogicznych powstają bardzo cenne bazy danych, ale skupiają się one - mamy nadzieję, że tylko na razie - na indeksacji akt metrykalnych oraz upamiętnianiu uczestników powstań narodowych lub żołnierzy wojen światowych².

Pragniemy zainteresować genealogów i nie tylko, źródłem, jakim są listy gończe, rzadko wykorzystywanym $\mathrm{w}$ badaniach genealogicznych, sporadycznie w historycznych, choć dla genealoga niezwykle interesującym, jeśli tylko nasz przodek wszedł w konflikt z prawem. Jest to materiał również bardzo ciekawy dla historyków i etnografów.

Zapewne wielu z nas zastanawia się, po kim odziedziczyliśmy kształt twarzy, ust, nosa, wzrost, a nawet charakter. Dlaczego przodek zmienił miejsce zamieszkania albo... zniknął ze wsi na długi czas? Wydaje się, że wyłącznie to źródło pozwala poznać wygląd ściganej osoby, a tym samym możemy dowiedzieć się, czy po dwustu latach mamy z naszym antenatem jakieś cechy wspólne.

W listach gończych z końca XVIII i początku XIX w. można znaleźć cenne informacje o warunkach życia chłopstwa, mieszczan, a czasem szlachty i możnowładztwa, dowiedzieć się, gdzie i kiedy przebywał dziadek-uciekinier i za co był ścigany, a w niewielu przypadkach także poznać okoliczności jego śmierci i osobę zabójcy,.

Dla badacza przeszłości własnej rodziny lub małej ojczyzny najcenniejsze będą zapewne informacje o: wyglądzie przodka i jego znakach szczególnych, cechach charakteru, jego stosunkach rodzinnych, nazwiskach, przezwiskach i charakterze wykonywanej pracy, właścicielu majątku/wsi, gdzie przodek mieszkał lub pracował, winie bądź popełnionym przestępstwie, sposobie ucieczki z więzienia albo aresztu, jeśli taka miała miejsce, odzieży, którą nosił, stanie jego majątku, jeśli antenat był osobą pokrzywdzoną w sprawie, przyczynie śmierci, miejscu odbywania kary.

Listy gończe w końcu XVIII i pierwszej połowie XIX w. na terenie Wielkopolski publikowano m.in. w: „Dziennikach Urzędowych Królewskich Regencji" w Poznaniu oraz w Bydgoszczy, a także w ich dodatkach, czy-

\footnotetext{
2 Przykładowo: projekt Lista odznaczonych Wielkopolskim Krzyżem Powstańczym - projekt powstał dla upamiętnienia osób biorących udział w powstaniu wielkopolskim, które zostały uhonorowane tym odznaczeniem; zawiera 22500 nazwisk, dostępny jest pod adresem http:/ / powstancywielkopolscy.pl/search.php (dostęp 15 czerwca 2016); projekt Polegli w pierwszej wojnie światowej - spis obejmuje zachowane $\mathrm{w}$ formie nagrobnych inskrypcji nazwiska poległych $\mathrm{w}$ trakcie działań wojennych w latach 1914-1918, dostępny na pod adresem http://www.polegli.forgen.pl/ (dostęp 15 czerwca 2016).
} 
li „Publicznych Donosicielach”, „Dziennikach Departamentu Kaliskiego”, "Dziennikach Urzędowych Województwa Kaliskiego", oraz czasopismach „Gazecie Południowo-Pruskiej”, ,Gazecie Poznańskiej”, ,"Gazecie Wielkiego Księstwa Poznańskiego".

Pierwsze listy gończe, jakie odnalazłyśmy w czasopismach, miały formę opisową i nie posiadały jednolitego układu. Jak można było zauważyć, z czasem ich zapis został sformalizowany: na wstępie podawano, kiedy, kto i jakie popełnił wykroczenie, następnie „upraszano” różnego typu władze (cywilne, wojskowe, osoby prywatne), aby jeśli poszukiwanego znajdą, odprowadziły do odpowiedniej instytucji/osoby, która podpisała się pod ogłoszeniem. Dalej podawano rysopis ściganego, wreszcie opisywano, jak był ubrany. Na końcu podawano datę wystawienia listu oraz urząd/osobę, która go wystawiła. Najczęściej listy wystawiały: Królewsko-Pruski Inkwizytoriat, królewskie regencje, sądy patrymonialne, sądy ziemsko-miejskie różnych miejscowości, landraci powiatów oraz osoby prywatne (właściciele majątków).

Część listu omawiająca wygląd podejrzanego zapewne przygotowywano, korzystając z formularzy i zapisów w księgach paszportowych ${ }^{3}$. Ważne jest, iż dziewiętnastowieczny paszport zawierał rysopis właściciela sporządzany według dwudziestu punktów: 1) imię i nazwisko, 2) stan, 3) ojczyzna, 4) miejsce stałego pobytu, 5) religia, 6) wiek, 7) wzrost podawany w stopach i calach, 8) włosy, 9) czoło, 10) brwi, 11) oczy, 12) nos, 13) usta, 14) zęby, 15) broda, 16) podbródek, 17) twarz, 18) cera, 19) postawa, 20) szczególne znaki.

Zatem jeśli nasz antenat popadł w konflikt z prawem i, chcąc uniknąć kary, uciekł wymiarowi sprawiedliwości lub samowolnie opuścił swego pana, możemy spróbować odszukać wydany za nim list gończy.

Korzystając z listów opublikowanych w języku polskim w wielkopolskiej prasie, przedstawimy przykłady ukazujące zróżnicowanie informacji, jakie genealog może w nim spotkać. Przykłady starałyśmy się ułożyć tematycznie, choć nie było to łatwe ze względu na bogactwo zawartych w nich informacji. Ułożyłyśmy je według:

- miejsca zamieszkania,

- cech osobowościowych i uzdolnień,

- złodziei,

- powstańców, żołnierzy i dezerterów,

- przypadków szczególnych, w tym morderstw,

- ucieczek z więzień i aresztów.

${ }^{3}$ Patrz więcej Główna Instrukcya tycząca się sprawowania Policyi paszportowey w Królewskich Państwach Pruskich, „Dziennik Królewskiey Regencyi w Poznaniu” 1817, nr 42, dodatek, s. 77. 


\section{Miejsce zamieszkania}

Z pewnością niejeden genealog miał w swoich poszukiwaniach przypadek, kiedy jakaś osoba pojawia się, a następnie znika z dokumentacji źródłowej. Nie wiadomo, gdzie jej szukać, a także, kiedy odeszła z rodzinnego domu. Powody takiego zniknięcia były zasadniczo trzy. Pierwszym było małżeństwo, drugim - chyba najważniejszym - praca. Trzecią przyczyną opuszczenia rodzinnych stron był oczywiście konflikt z prawem i ucieczka przed wymiarem sprawiedliwości. Warto sięgnąć do listów gończych ${ }^{4}$, które niejednokrotnie pokazują drogę przemieszczania się poszukiwanego. Opisują, gdzie się urodził, w jakim miejscu i w jakim charakterze pracował, oraz gdzie przebywał w międzyczasie, zanim dopuścił się przestępstwa. Mogą również informować o porzuceniu rodziny czy posiadaniu krewnych w innej miejscowości.

W poniższych przykładach można zaobserwować wędrowne życie, nie tylko pracowników najemnych i pracowników folwarków ale także rzemieślników, zarządców, ekonomów i dzierżawców a niekiedy i szlachciców.

Oskarzony względem popełnienia kradziezy koni Woyciech Przepiera ktory na ostatku w Piarach blisko Wrzeszni ${ }^{5}$ u chłopa Łukasza słuzył maiący lat 60, ze Szrodki mile od Poznania urodzony, wzrostu wielkiego, grubey i okrągłey twarzy, czarnych włosow, i szarych oczow dzisiay rano przed 8. godziną z tuteyszego magistrackiego więzienia uciekł. Nosi na sobie kaftan niebieski, płócienne spodnie, na głowie starą czerwoną sukienną czapkę, a na nogach boty. [...] W Gnieźnie dnia 30. Kwietnia 1800.

Burmistrz i sąd ${ }^{6}$.

Opisany poniżey Jędrzey Schulz, który przed 2ma laty służył w Bolewicach Powiatu Bukowskiego, a w przeszłym roku w Niewierzu Pow. Szamotulskiego za owczarka, także przed kilku tygodniami robił iako najemnik we młynie Lesznik Powiatu Międzychodzkiego, stamtąd zaś udał się do Podrzewia Pow. Szamotulskiego, gdzie zmowu robił iako najemnik u gospodarza Schefler, okradł w dniu 10. m. b. owczarza Samuela Reschke w Kwilczu, dobywszy się do niego gwałtownym sposobem przez piec, wziął mu z skrzyni 800 Tal. grubą monetą, po większej części całemi talarami. Oddany nałogowi pijaństwa, maiąc pieniądze, przesiaduie po kilka dni w szynkowni. [...]

Opisanie. - [...] mieysce urodzenia Pożarowo Pow. Szamotulskiego; miejsce pobytu, włóczęga; ewannielik; wieku, lat 30; wzrostu, 5 stóp 3 cale; włosy, iasnoblond;

\footnotetext{
${ }^{4}$ Korzystając z "Dzienników Urzędowych" oraz „Publicznego Donosiciela”, można również znaleźć wiele informacji dotyczących poszukiwanych przez rodziny, którzy „za chlebem” poszli w świat, lub „złośliwe opuścili” swych małżonków. Szczegóły te były potrzebne, aby poszukiwanych urzędowo uznać za zmarłych. Informacje te publikowano w Obwieszczeniach.

${ }^{5}$ Pogrubienia pochodzą od autorek.

6 "Gazeta Południowo-Pruska" 1800, nr 37, s. 8.
} 
[...] Poznaki: ryssa w iedney stronie nosa od uderzenia, iedna noga przy kostkach nabrzmiała i sina. $[\ldots]^{7}$.

Opisany poniżey Karol Jan Herrman Mettke, (syn burmistrza Mettke w Krosnach) który się od nieiakiego czasu uczył gospodarstwa w Król. Ekonomii Międzychodzkiey, oddalił się w nocy z 27. na 28. Czerwca r. b., przedawszy dnia poprzedniego płaszcz pisarza Lehmann, a prócz tego zabrał: 1) pańską klacz wierzchową, karą z strzałką i 2( nowe zupełnie siodło z całym rzędem Inspektora Jacobi; 3) pisarzowi Lehmann dwie pary spodni i parę ostrog srebrnych. [...] Opisanie. - Nazwisko, Mettke; imiona Karol Jan Herrman; mieysce uriodzenia, Krosna; mieysce pobytu, Wkonomia Międzychodzka; ewanielik; wiek, urodził się dn. 30. Marca 1816 [...] mowa niemiecka i franzuska; znaki szczególne, bardzo krótki wzrok. - [... $]^{8}$.

Poniż bliżej opisany młynarczyk Walenty Pa przycki, który się u młynarza Andrzeja Grązlewicza w Zaniemyślu w nauce znajdował, został przez nas o fałszerstwo monety do indagacyi kryminalnej pociągnięty. Paprzycki udał się z Naniemyslu do Żerkowa w powiecie Wrzesińskim położonego, do swych rodziców, skąd jednak potajemnie się wydalił, i pomimo wszelkich śledztw pobyt jego teraźniejszy wypośrodkowanym być nie może. [...] - Rysopis: miejsce urodzenia, Żerków, miejsce zamieszkania Zaniemyśl; religia, katolik; wiek, 19 lat; [...] mowa, po polsku i cokolwiek po niemiecku; szczególne znaki, słyszy cokolwiek tępo. [...] $]^{9}$.

Nieiaki Marcin Mikołayczak i syn iego Łukasz, którzy w więzieniu tuteyszem [koźmińskim] za kradzież siedzieli, ściągnęli na siebie mocne podeyrzenie, że zaraz po odzyskaniu swoiey wolności w dniu 7. września r. z. na publiczneu drodze między Wielkowyią i Łuszczanowem rabunku się dopuścili. [...]

$$
\text { Rysopisy: }
$$

1) Marcin Mikołayczak, rodem z wsi Oporowa pod Gostyniem, ostatnie iego mieszkanie było w Słupi pod Środą; katolik; miał wysokości 5 stóp 3 cale; lat 50; [...]

2) Lukasz Mikołayczak, rodem z Pogorzelicy pod Żerkowem; obecnie zaś zamieszkiwał w Słupi pod Środą; ma lat $20[\ldots]^{10}$.

Kupiec Samuel Fried enthal, który od półroku z Nowego Yorku do swoich rodziców do Gołańczy powrócił i od 5. Sierpnia r. b. w areszcie wexlowym przy podpisanym Sądzie znajdował się, zbiegł dnia $23 \mathrm{~m}$. b. przed południem z tutejszego więzienia. [...] - Ryso pis kupca Samuela Friedenthal: religia, żydowska; wiek 28 lat; [...] Odzież: czarna sukienna wołoszka z kołnierzem aksamitnym, czarna jedwabna westka, dito chustka na szyję, biała podkoszulka, brunatne sukienne spodnie, krótkie bóty, czarna sukienna czapeczka z jedwabnemi kałasikami ${ }^{11}$.

Niejaki Kazimierz Klose, iako też Krauze nazwany, który iedney gwałtowney wykonaney kradzieży w wsi niskiey Schüttlau [Żuchlów] pod Głogowem leżącey podeyrzanym iest. Krótko przed swym aresztowaniem na dniu 5go Lipca r. b. z opusc-

7 „Publiczny Donosiciel” 1832, nr 40, s. 551-552.

8 „Publiczny Donosiciel” 1832, nr 28, s. 439.

9 "Publiczny Donosiciel” 1841, nr 8, s. 115-116.

10 „Publiczny Donosiciel” 1822, nr 36 s. 399-400.

11 „Publiczny Donosiciel” 1841, nr 1, s. 1-2. 
zeniem swy żony i piąciu dzieci, znalazł sposobność uciec z wsi Gorschen pod Schlichtyngowem.

Obwiniony z górney Przyczyny [Górna Przyczyna] pod Wschową leżącey rodem, i mieni się być ciesielczykiem. [...]

\section{RYSOPIS.}

Obwiniony iest 37 lat stary, ewanielickiey religii, małey postawy, czarnych na głowie włosów, odkrytego czoła, zwyczaynego nosa i ust, brody czarno zarastaiącey, i pod podbródkiem włosami obrosły, podbródka okrągłego, twarzy koloru czarnego. Przy swey ucieczce nosił tenże czarną aksamitną krymkę, krótki szaro sukienny kaftan, granatowe płócienne spodnie, i złe bóty ${ }^{12}$.

\section{Cechy osobowościowe i zdolności}

Dla genealogów wygląd przodka i cechy charakteru będą bardzo cennymi informacjami. O ile na temat ubrań różnych warstw społecznych w różnych regionach napisano wiele prac ${ }^{13}$, o tyle żadne źródło (a już z pewnością księga metrykalna) nie odpowie na pytanie, jak mógł wyglądać nasz przodek. W listach znalazły się nie tylko podstawowe informacje dotyczące wyglądu (m.in. wzrost, kolor oczu i włosów, wyznanie), ale także cechy wyróżniające go, np. blizny, tatuaże, braki w uzębieniu, zez, kolczyki, dziwne spojrzenie, seplenienie, sposób chodzenia, nałogi, znajomość języków (w jednym z listów poszukiwany znał ich sześć), oraz umiejętność pisania i liczenia.

Sławny złodziej Mikołaj Bielecki, którego rysopis niżej nastąpi, w skutek gwałtownego wyłamania się z tutejszego więzienia w dniu 26. Grudnia r. z. uciekł. [...] - Rysopis Mikołaja: religia katolicka, stary 26 lat., wzrost 5 stóp 5 cali, włosy ciemnobrunatne, czoła wąskiego, brwi czarne, oczy ciemnobrunatne, nos haczykowaty, usta duże, broda ogolona, podbródek i twarz okrągłe, kolor twarzy czerstwy, postawy silnej, mówi trochę poniemiecku i popolsku. Szczególne znaki: nosi kilka mosiężnych pierścionków na palcach i ma mały kolczyk i potrafi na pozor minę przybrać człowieka dobrego serca - Odzież: cwylichowa sukmana, cwylichowe spodnie, NB. bez czapki i obuwia uciekł14.

Nieiaki Darowski, który się także nazywa Schenk, i mieni się bydź Porucznikiem legii rossyysko-niemieckiey, obwiniony o różne występki, wyniósł się potajemnie do Warszawy, gdzie się niekiedy za Generała udawał. [...]

Rysopis.

Darowski alias Schenk ma około 22. lat, wzrostu miernego, figury wysmukłey, twarzy podługowatey, niebieskich oczów, włosów płowych, długiego cokolwiek kończatego

12 „Publiczny Donosiciel” 1822, nr 20, s. 336-337.

${ }^{13}$ Zob. m.in.: Ł. Gołębiowski, Ubiory w Polsce od najdawniejszych czasów aż do chwil obecnych, Kraków 1861; J. Kitowicz, Opis obyczajów za panowania Augusta III, Poznań 1840; O. Kolberg, Lud. Jego zwyczaje, sposób życia, mowa, podania, przysłowia, obrzędy, gusła, zabawy, pieśni, muzyka i tańce, Kraków 1857-1890.

14 „Publiczny Donosiciel” 1843, nr 3, s. 49. 
nosa i mało co obrosły. Mówi po polsku i po niemiecku, a w ucieczce z Warszawy miał na sobie ciemno-granatowy płaszcz, z kołnierzem sobolowym cokolwiek iuż podszarzanym; w Bydgoszczy ma mieć żonę $e^{15}$.

Pewien Tomasz forszpan moy, ktory u mnie ieszcze nie puł roku służył, a swoie zasługi za cały rok wybrał i liberyą nową wziął, uciekł mi (co tenże Tomasz każdego roku czynić zwykł) przed kilku dniami z Ruszkowa pod Gostyniem. Jest on małego wzrostu i ma około 18 lat, ma ciemno - białawe włosy w krotki warkocz związane $[\ldots]$.

Przestrzegam zatem każdego o tym zdradzieckim i niebezpiecznym człowieku, który zawsze przed S. Janem z służby ucieka, i Panów swych przez swoie w początku dobre postępowanie tak oszukiwać umie, że nietylko swe zasługi za cały rok lecz także i liberyą wyłudzić z nich potrafi. Że zaś ma także znać professyą kowalską, przeto domyślić się należy, że może bydź, iż urządzi się także iako kowalczyk u iakego kowala na wsi ${ }^{16}$.

\section{Złodzieje}

Najbardziej pospolitym przestępstwem była kradzież, a więc za złodziejami wystawiano najwięcej listów. Najczęściej kradziono pieniądze, żywność, zwierzęta, drobne przedmioty domowego użytku, odzież, a także przedmioty nietypowe jak pieczęcie urzędowe, legitymacje podróżne, paszporty, świadectwa rzemieślnicze. W wielu litach wymieniano skradzione przedmioty dzięki czemu jeśli nasz antenat był stroną pokrzywdzoną można odtworzyć jego majątek.

Dnia 13. Listopada między godziną czwartą i piątą po południu lokay moy imieniem Jan z przezwiska nie iest mi pamiętny, ponieważ testimonium swoie wykradl, rozbił mi gwałtownym sposobem szkatułę, pieniądze zabral, srebra sztuk 16, zegarek, bieliznę, znaczną część garderoby moiey i rożnych rzeczy nakradłszy zbiegł. Dla poznania onegoż opisuje się z postaci wzrostu średniego a bardziey niskiego w plecach czyli w barkach szeroki, włosów czarnych, twarzy brunatney, oczu czarnych wielkich, ma zwyczay uśmiechać się $[\ldots]^{17}$.

Dnia wczorayszego uszedł mi parobek moy z naylepszym koniem zaprzężnym. [...] Zbieg ten nazywa się Bogumił (Gottlieb), ma 20 kilka lat, miernego wzrostu, brunatnych oczow i takichże włosów w warkocz plecionych. [...] Koń iest 7letni wałach niezewszystkiem myszaty maści z białą małą gwiazdką, 3-4 cali rosły, czarny pasek na karku, czarnawą grzywę i rakowy ogon i pod szyia włos nieco wyliniały. Człowiek

15 „Dziennik Urzędowy Królewskiej Regencji w Poznaniu” 1816, nr 3, s. 55. Listy gończe przez pierwsze dwa miesiące wydawania „Dziennika” były w nim publikowane na końcu numeru. W lipcu 1816 r. rozpoczęto druk dodatku do „Dziennika”, czyli „Publicznego Donosiciela”, do którego przeniesiono listy.

16 „Gazeta Południowo-Pruska" 1803, nr 66, s. 10.

17 „Gazeta Poznańska” 1808, nr 92, s. 10. 
ten zabrał z koniem 3 uzdy, między którymi, iedna na wierzchowca, tudzież ślę czerwonym friesem podszytą. W Poznaniu dnia 31. stycznia $1806^{18}$.

Zbieg polski, Paweł Piorkowski, z Starołęki pod Poznaniem rodem, który opatrzony paszportem Magistratu Policyi w Toruniu z d. 25. Września r. z. Nro 104. Przybył w Powiat ostrzeszowski, okradł niejakiego Antoniego Bagińskiego w Kolonii Kamillenthal rzeczonego Powiatu, w nocy z 15. na 16. m. b. z następuiącey odzieży:

1. płascz nowy z wielkim kołnierzem $\mathrm{z}$ szarego nakrapianego sukna $\mathrm{z}$ flanelowem podbiciem;

2. suknia zwierzchnia nowa $\mathrm{z}$ granatowego sukna, białem płótnem podbita, z żółtemi guzikami;

3. para nowych spodni z takiegoż, iak płascz, sukna;

4. para szarych cweliszkowych spodni iuż zchodzonych;

5. para nowych botów do woskowania;

6. czerwona katunowa kamizelka;

7. kamizelka katunowa w zielone i białe kropki;

8. kamizelka sukienna ciemnozielona;

9. czerwona iedwabna chustka na szyię;

10. chustka na szyię w czerwone paski;

11. perkalowy kołnierz na szyię;

12. nowy kapelusz okrągły i

13. gotowizną 14 dytków;

i uszedł.

Ma lat 24, wzrostu 5 stóp 1 cal, włosy brunatne, okrągłe czoło, brwi brunatne, oczy niebieskie, nos podługawy, usta mierne, brunatną brodę, podbródek okrągły, twarz podługawą, cerę zdrową, postawę średnią, bez szczególnych znaków. [.... $]^{19}$.

Pocztylion moy imieniem Jozef, rodem, iak powiadal, z Wilczyna w Prusach zachodnich, okradł pocztę wozkową, która o iednyn koniu ztąd do Koła i z tamtąd na powrot chodzi przez Russocice (gdzie się także urząd pocztowy znayduie, dla odbierania i oddawania listów i rzeczy) zabierając listy i cztery worki z pieniędzmi i uciekł, zostawiwszy konia i wózek w gościńcu wsi Wilkow a pod Koninem.

[...] Złodziey ten iest wzrostu małego, ma lat 18 do 20. chudy, twarzy podłogowatey, ma oczy i włosy czarne, suknią polską iasnobłękitną, kamizelkę niemiecką czarnoprąźkowatą, spodnie płócienne i kapelusz okrągły. Ktoby go złapał i przystawił, będzie względem kosztow wynadgrodzony ${ }^{20}$.

\section{Powstańcy, żołnierze i dezerterzy}

Osoby zainteresowane dziejami powstań narodowych znajdą listy wystawione za uczestnikami powstań 1831, 1846 i 1848 roku. Bardzo wiele listów opisuje dezerterów z wojska z podaniem ich szarży, formacji oraz miejsca stacjonowania oraz, jeśli zostali schwytani, odwołaniem akcji poszukiwawczej.

18 "Gazeta Południowo-Pruska” 1806, nr 10, s. 7-8.

19 "Publiczny Donosiciel" 1819, nr 32, s. 326-327.

20 "Gazeta Południowo-Pruska" 1795, nr 71, s. 6. 


\section{Eidetheits: polizet.}

\author{
Sted brtefe.
}

S8.

On ben Eagen yom 4. bis 6. b. Wr.; finb

ote nadbejeidineten Solbaten bes sontglidyen

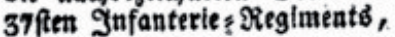

Qus. bem INogilnoer Rrelfe:

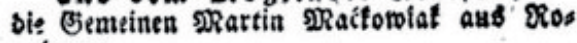
źattno,

Balentin Sfubarga aus giemolno, unb

ber Beftut Jatob ₹ursti aus ₹rjemestzo;

aus bem şnefener seetfe:

bie Semetnen SRartia Roniecjfy aub IRnis ()

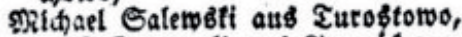

भiuguft Snowactl aub Tarsạbfowo,

Tobann 2 Ralina aus $\widehat{E}_{j}$ ctuieiewo,

Gofeps Rutato aus cielmomo unb

SRartin इtwarbowstl aus Janfowo,

bie Reteuten Sofepb Betnajat aus 2nis d)owo,

Balentin Twaństl aus Bracişzemo,

Sbomas 3utfowdti aus Sotolnifl unb

Det unfidiere Rantonift Jobann Solaret aus Nuichowo,

aub ber Éarnifon \$born Defertirt.

\section{Policya bezpieczefistwa.}

\author{
Listy got $\mathrm{g}$ ge.
}

$\mathrm{W}$

dniach od $4 \mathrm{go}$ do $6 \mathrm{go} \mathrm{m}$. d. zbiegli portizéy opisani żolnierze z Król 37. pótku piechoty,

z Powiatu.JMogilinkiego:

Zołnierze Marcin Maćkowiak z Roianny,

Walenty Szubarga z Niewolna i

Rekrut Jakob Turski z Trzemeszma,

z Powiatu Gniznińokiego:

Zołnierze: Marcin Konieczny z Mnichowa, Michał Salewki z Turostowa, Augustyn Snowacki z Jarząbkowa,

Jan Malina z Czerniejewa,

Jozef Kniawa z Cielmowa i

Marcin Twardoweki z Jankowa,

Rekruci Jozef Bernarczak z Mnichown,

Walenty Jwański z Braciszewa,

Tomasz Zurkowski z Sokolnik i

niepewny kantonista Jan Solarek z Mni. chowa,

z garnizonu Toruńsklego.

Fragment wykazu uciekinierów z 37 Pułku Piechoty stacjonującego w 1830 roku w Toruniu, Dodatek Publiczny do Dziennika Urzędowego królewskiej Regencji w Bydgoszczy 1830, nr 52, s. 938.

Niżey opisany służący chłopiec Kazimierz Musiałowski, który roku zeszłego do Polski wyszedł, służył w tamecznem woysku powstańców i niedawno do Sulmierzyc powrócił, oddalił się iednak niedługo ztamtąd i teraźnieyszy iego pobyt nie mógł dotychczas być wyśledzonym [...]. Opis anie Kazimierza Musiałowskiego. Mieysce urodzenia: podrzutek, niewiadomo gdzie się urodził; oyczyzna, niewiadoma; mieysce zwyczayne pobytu, niepewne iako służącego; katolik; służący; wielu lat 19; wzrostu 5 stóp; włosy, ciemnoblond; czoło, pokryte; brwi, blond; oczy niebieskie; nos gruby; usta, zwyczayne; zęby, spełna; podbródek, podługowaty; cera, czerwonawa; twarz krągła i mówi popolsku. Odzież. Surdut, kurtka niebieskie z guzikami cynowemi Nro. 4; westka, spodnie szare płócienne; ciżmy, czapka niebieska ${ }^{21}$.

Teodor Snowadzki, chłopiec służący, rodem z Łopuchowa Pow. Obornickiego, pociągnięty przez Królewski Inkwizytoryat w Wschowie do indagacyi z powodu oddalenia się do Polski, opuścił cichaczem wskazne mu na pobyt mieysce Belencin Pow. Wschowskiego i teraźnieyszy pobyt iego nie iest wiadomym. [... $]^{22}$.

21 „Publiczny Donosiciel” 1832, nr 31, s. 463-464.

22 „Publiczny Donosiciel” 1832, nr 40, s. 551. 


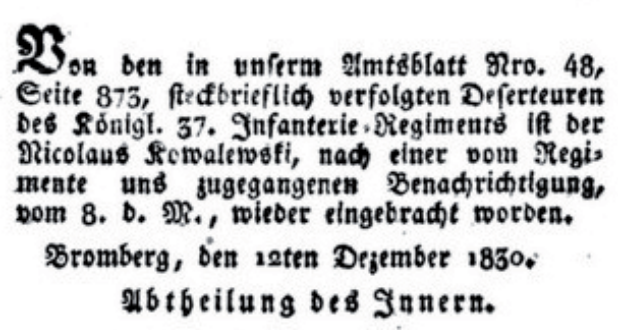

2 dezerterów Król. 37. półku piechoty w Dzienniku naszym urzędowym Nro. 48., stronnica 873. listem gończym ścigarych, dostawiony znowu został Nixołay Kowalewski podług uwiadomienia półku z d. $8 . \mathrm{m}$. b.

Bydgoszcz, daia 12. Grudnia 1830.

Wydział spraw wewnętrznych.

Przykład odwołania listu gończego, Dodatek Publiczny do Dziennika Urzędowego królewskiej Regencji w Bydgoszczy 1830, nr 52, s. 945.

\section{Przypadki szczególne oraz morderstwa}

Oprócz złodziei poszukiwano również wielu: morderców, oszustów i lichwiarzy, fałszerzy dokumentów, bigamistów, bandytów napadających na podróżnych, prostytutek, podpalaczy. Co ważne bardzo często listy za mordercami opisywały w miarę dokładnie przebieg zdarzenia.

O mocne podeyrzenie podłożenia ognia w dniu 22. Września r. b. do indagazyi kryminalney pociągniony szewc Jakób Frasunkiewicz, w nocy z 13. na 14. b. m. w Dobrzycy, gdzie tenże dla kommissyi lokalney $\mathrm{w}$ tamecznym komunalnym więzieniu był osadzony, przez gwałtowne wyłamanie się, przy pozostawieniu kaydan naręcznych, znalazł sposobność zbiegnienia. [... $]^{23}$.

Mieszkowo. Pod dniem 30. p. m. wieczorem o godzinie 5. mieszczanin i młynarz Szulc, w młynie Mostki nazwanym, od tuteyszego miasta ćwierć mile leżącym, przez nieznaiomego do niego przybyłego człowieka namyślnie pistoletem $\mathrm{z}$ pod sukni wyiętym, takowym sposobem $w$ brzuch postrzelony został, iż dnia 31. ej. M. o godzinie 12. w południe umarł. Tenże człowiek iako skoro to morderstwo popełnił, zaraz uciekł $[\ldots]^{24}$.

Dnia 22. Maia r. b. w Gross Bressen w powiecie Trzebnickim Departamentu Wrocławskiego, trzech obcych poniżey, ile można było, opisanych żydów, dopuściło się grubego oszukaństwa. Wspomnionego właśnie dnia przyszedł przystoynie ubrany młody człowiek do przędzarza Karola Martsch tamże, i opowiadając mu iak gwałtownie potrzebował pieniędzy prosił go, ażeby mu na 4 tygodnie pożyczył 50 Tal., ofiarując mu w zastaw złoty na pozór łańcuch. W tym samym czasie przybyło także niby przypadkowo dwóch podróżnych żydów, którzy otaxowali łańcuch na 200 Tal., tak iż

23 „Publiczny Donosiciel” 1832, nr 43, s. 631-632.

24 "Posener Intelligenz-Blatt zum Nuzzen und Beften des Publici” 1802, nr 14, s. 143-144. 
p. Martsch zebrał wszystke swoie pieniądze, wyliczył obcemu człowiekowi 40 Tal. i oddał mu swoy srebrny zegarek. Łańcuch, iak się późniey okazało, nie był złoty lecz tombakowy i rzecz widoczna iż ów człowiek, był w porozumieniu z żydami, którzy, z pronuncyacyi wnosząc, do W. Xięstwa Poznańskiego należą. [...]. Opisanie. Człowiek, który łańcuch przedał, może mieć 30 lat, wzrostu 5 stóp, bez brody, ma brunatne włosy i takież oczy; miał na sobie frak sukienny brunatny, czerwoną czapkę z czarnym barankiem, okulary na nosie z czterema szkłami. Z dwóch innych, ieden może mieć 40, drugi 20 lat i obydway, iak się zdawało, byli zwyczayni szachraje żydowscy ${ }^{25}$.

Niżej opisana, za kurewstwo pokątne na trzechmiesięczne więzienie i detencyą aż do powzięcia uczciwego sposobu do życia wskazana A n n a $\mathbf{M}$ a r c u s e przed kozą zemkła. [...]. R y s o pi s: Miejsce urodzenia, Skoki; miejsce pobytu, Poznań; religia, żydowska; wiek, 18 lat $[\ldots]^{26}$.

\section{Ucieczki z więzień i aresztów}

Sposób przedstawienia ucieczek z więzień i aresztów, oraz „umykanie” strażnikom prowadzącym aresztanta do fronfestu są bardzo ciekawe. Im starszy list gończy, tym barwniejszy jest opis. Z czasem stały się one krótsze, i pozbawione szczegółów, które w wielu przypadkach ośmieszały pruski wymiar sprawiedliwości.

Gdy w nocy z dnia 23. Maia r. b. przez wyłamanie gwałtowne przegradzaiącey ściany, Inkulpaci z dwóch celów do iedney zbiegli się i o północy, podczas odbywaney przez inspekcyą więzienia rewizyi, gwałtownie na rewiduiących i zbroinych żołnierzy Rossyiskich uderzyli, oraz powydzieranemi żołnierzom karabinami tyle oporu dokazali, iż mimo wszelkiey usilności z tych pięciu zbrodniarzy o wielokrotne kradzieże obwinionych, w kaydanach znayduiuących się, przez małe okienko nade drzwiami będące z inkwizytoryatu Kaliskiego pouciekali, przeto następne opisa fizognomii onych do publicznej podaię się wiadomości. [... $]^{27}$.

Niżej lepiej opisanemu, o powtórną kradzież tu uwięzionemu Marcinowi Pachciarczykowi alias Kasprzaczykowi udało się dziś w nocy z lazaretu tutejszego więzienia uciec, ile on przez gwałtowne odgięcie żelaznych sztabów przed oknem, na dach przy temże oknie znajdujący się dostawszy się, wkręcił się ztamtąd na pobliski okien kościelnych dach, i przez okno kościoła Bernardynów dostał się. Gdy nam na schwytaniu tegoż niebezpiecznego zbrodniarza, który będąc na nogi okuty w żelazny pręt, a który z sobą zabrał, wiele zależy $[\ldots]^{28}$.

\footnotetext{
25 "Publiczny Donosiciel” 1832, nr 36, s. 524-525.

26 „Publiczny Donosiciel” 1844, nr 41, s. 751.

27 "Gazeta Wielkiego Księstwa Poznańskiego" 1815, nr 51, s. 688.

28 "Publiczny Donosiciel” 1836, nr 8, s. 120.
} 
Pociągnięty do indagacyi za łupiestwo na publicznej drodze parobek Marcin Drzewiecki, który w kajdany od ręki do nogi okuty był, zbiegł przewodnikowi na dniu wczorajszym to jest 11. b.m. na transporcie między Kostrzynem a Swarzędzem. $[\ldots]^{29}$.

Z więzienia tuteyszego $\mathrm{w}$ nocy $\mathrm{z}$ dnia 22. na 23. Czerwca $\mathrm{r}$. b. przez gwałtowne wyłamanie drzwi uciekł, niey opisany o kradzież posądzony Franciszek Pachura i córka iego Agniszka Pachura. [... $]^{30}$.

\section{Zakończenie}

Listy gończe mogą stać się bardzo cennym źródłem wiedzy nie tylko dla genealoga i regionalisty, ale także materiałem badawczych dla historyków, etnografów, językoznawców i dialektologów. Zaprezentowane przykłady nie wyczerpują bogactwa informacji zawartych w listach gończych. Mamy nadzieję, że zainteresują one potencjalnych badaczy ${ }^{31}$.

W tym miejscu warto wspomnieć, że podobne informacje przynoszą tzw. wykazy wypędzonych (przybierały one różne tytuły) z Rejencji Poznańskiej i Bydgoskiej, które publikowane były także w dodatkach do Dzienników Urzędowych tych rejencji. Podawały one informacje o obcokrajowcach (w tym mieszkańców zaboru rosyjskiego i austriackiego) wydalonych z państwa puskiego za róznorakie przewinienia ${ }^{32}$.

Zasygnalizowana tematyka listów gończych, pokazuje wiele możliwości ich wykorzystania. Nie bez znaczenia jest także liczebność i dostępność tego typu materiałów źródłowych, bowiem prawie każdy numer czasopisma publikował listy, a w „Publicznym Donosicielu” w niemalże każdym numerze było kilka. Czasopisma, w których publikowano listy gończe, już w dużej liczbie dostępne są w Wielkopolskiej Bibliotece Cyfrowej.

29 "Gazeta Wielkiego Księstwa Poznańskiego" 1831, nr 110, s. 564.

30 "Publiczny Donosiciel” 1831, nr 27, s. 301.

31 Więcej przykładów zob. D. Gucia, J. Lubierska, "Jako cię widza, tako cię pisza". Obraz Wielkopolanina w świetle listów gończych 1 połowy XIX wieku, Poznań 2014.

32 Pierwszą próbę analizy wykazów wypędzonych podjęłyśmy podczas wystapienia na III Ogólnopolskiej Konferencji Genalogiznej w Brzegu, patrz więcej: J. Lubierska, D. Gucia, Przodek na bakie $z$ prawem. Listy gończe i spisy wypędzonych jako źrodto w badaniach genealogicznych, „Varia Genealogica” 1(2017), s. 202-204. 


\section{Bibliografia}

„Amtsblatts der Königlichen Regierung zu Posen / Dziennik Urzędowy Królewskiey Regencyi w Poznaniu", roczniki 1816-1850.

"Gazeta Południowo-Pruska", roczniki 1795, 1800, 1803, 1808.

"Gazeta Poznańska", roczniki 1808, 1812.

"Gazeta Wielkiego Księstwa Poznańskiego", roczniki 1808, 1815, 1831.

Główna Instrukcya tyczaca się sprawowania Policyi paszportowey w Królewskich Państwach Pruskich, „Dziennik Urzędowy Królewskiej Regencji w Poznaniu” 1817, dodatek do nr. 42.

Gucia D., Lubierska J., "Jako cię widza, tako cię pisza". Obraz Wielkopolanina w świetle listów gończych 1 połowy XIX wieku, Poznań 2014.

Instruktion für die Dorfschulzen, Gemeiderschreiber und Dorfgerichte in Gutpreussen. De Dato Posen, den 17. Juny 1795 / Instrukcya dla Sołtysow, pisarzow i sadow wiejskich w Prusiech południowych. Dan w Poznaniu, dnia 17. Czerwca 1795 Roku.

Lubierska J., Gucia D., Przodek na bakie z prawem. Listy gończe i spisy wypędzonych jako źrodło w badaniach genealogicznych, „Varia Genealogica” 1(2017), s. 202-204.

Kommissya Porządkowa Cywilno-Woyskowa Woiewodztwa y Powiatu Poznańskiego, Gdy wielorakie doświadczenie nauczyło..., Poznań 1790.

Pihan-Kijasowa A., Gucia D., „Dziennik Urzędowy Królewskiej Regencyi w Poznaniu” z dodatkiem "Publiczny Donosiciel" jako źródło do badań dziewiętnastowiecznej polszczyzny wielkopolskiej, [w:] W kręgu dawnej polszczyzny, red. M. Mączyński, E. Horyń, E. Żmuda, Kraków 2015, t. II, s. 83-102.

„Posener Intelligenz-Blatt zum Nuzzen und Besten des Publici”, roczniki 1802, 1805.

„Oeffentlicher Anzeiger. Beilage zu .... des Amtsblatts der Königlichen Regierung zu Bromberg / Publiczny Donosiciel. Dodatek do Dziennika Urzędowego Królewskiey Regencyi w Bydgoszczy", rocznik 1830 i 1841.

„Oeffentlicher Anzeiger. Beilage zu .... des Amtsblatts der Königlichen Regierung zu Posen / Publiczny Donosiciel. Dodatek do Dziennika Urzędowego Królewskiey Regencyi w Poznaniu", roczniki 1816-1850.

Joanna Lubierska, Dobrosława Gucia

\section{Skonfliktowany z prawem przodek. Listy gończe końca XVIII i pierwszej połowy XIX w. jako źródło w badaniach genealogicznych}

\section{Streszczenie}

Artykuł prezentuje listy gończe jako nowe, ciekawe i bardzo cenne źródło, które może być wykorzystane do badań genealogicznych. Na przykładzie listów gończych publikowanych w informacyjnej i urzędowej prasie poznańskiej, wydawanej od końca XVIII do drugiej połowy XIX w., zaprezentowano bogactwo informacji w nich zawartych. Badacz przeszłości własnej rodziny lub małej ojczyzny może w listach znaleźć wiadomości m.in. o cechach charakteru poszukiwanego, jego stosunkach rodzinnych, charakterze wykonywanej pracy, sposobie ucieczki z więzienia lub aresztu, odzieży, którą nosił, a - co może być szczególnie cenne - o jego wyglądzie.

Słowa kluczowe: genealogia, listy gończe, Wielkopolska XVIII i XIX w. 


\title{
An ancestor in conflict with law. Arrest warrants from the late $18^{\text {th }}$ and early $19^{\text {th }}$ century as a source in genealogy investigations
}

\begin{abstract}
The article demonstrates how arrest warrants can be seen as a new, interesting and valuable source, helpful for genealogy investigations. Arrest warrants published in Poznań press (both newspapers and official bulletins) between the late $18^{\text {th }}$ and mid- $19^{\text {th }}$ centuries are used to demonstrate how much valuable information can be found therein. In those warrants, family or local community researchers can find information regarding the personality of the wanted person, their family relations, profession, how they escaped prison or custody, what clothes thy wore, and - what might be particularly valuable - their appearance.
\end{abstract}

Keywords: genealogy, arrest warrants, Greater Poland in the $18^{\text {th }}$ and $19^{\text {th }}$ centuries 